\title{
PLEISTOCENE PERIGLACIAL TOPOGRAPHY IN SOUTHERN AFRICA
}

\author{
By G. W. A. Sparrow \\ (Department of Geology, University of Natal, Pietermaritzburg, Republic of South Africa)
}

\begin{abstract}
Studies in the south-eastern part of the Drakensberg mountains and the Basutoland uplands, above the $6,000 \mathrm{ft}$. ( $1,830 \mathrm{~m}$.) level, of Southern Africa have yielded evidence for a periglacial regime during the Pleistocene. The limited earlier work in Southern Africa suggested that the Pleistocene climate was too dry for glaciation to have occurred, but the existence of oversteepened slopes, solifluction slumps and cirques is indicative of a periglacial environment. There is some correlation between the respective altitudes and latitudes of these periglacial features.
\end{abstract}

RÉsumé. Topographie périglaciaire pléistocène en Afrique du sud. Des études dans la partie sud-est du massif du Drakensberg et dans les hauts du Basutoland au-dessus de 6 ooo pieds ( $130 \mathrm{~m}$ ) en Afrique du sud ont montré l'évidence d'un régime périglaciaire pendant le pléistocène. Les travaux limités antérieurs en Afrique du sud suggéraient que le climat pendant le pléistocène était trop sec pour donner naissance à une glaciation mais l'existence de pentes renforcées, de coulées de solifluction et de cirques indique un environnement périglaciaire. Il existe quelque corrélation entre les altitudes et latitudes respectives de ces formations périglaciaires.

Zusammenfassung. Pleistozäne Periglazial-Topographie in Südafrika. Untersuchungen im südöstlichen Teil der Drakensberg gebirge und im oberen Basutoland in Höhen von über 6 ooo Fuss (I $830 \mathrm{~m}$ ) erwiesen periglaziale Verhältnisse während des Pleistozäns. Die begrenzten früheren Arbeiten in Südafrika nahmen ein pleistozänes Klima an, das zu trocken für die Entwicklung einer Vergletscherung war; doch deutet das Vorkommen von übersteilten Hängen, Solifluktionsdecken und Karen auf eine periglaziale Ausprägung hin. Zwischen den jeweiligen Höhen- und Breitenlagen dieser Periglazialerscheinungen besteht eine gewisse Beziehung.

\section{INTRODUCTION}

This study discusses evidence for a Pleistocene periglacial regime in Southern Africa as shown by landforms in the south-eastern part of the Drakensberg mountains and the Basutoland uplands. Because previous local work is almost non-existent, most of the information is based upon the author's own field studies.

Both du Toit (195!, p. 472-73) and Kojot (1948, p. 15) suggested that Southern Africa was too dry during the Pleistocene for glaciation to have occurred. Neither of them seems to have considered the alternative of a periglacial climatic regime, despite the pioneer work of Łoziński ( I 909) having appeared over four decades previously. Such an alternative appears to have been ignored until quite recently when Alexandre ( 1962 ) described periglacial landforms in the higher areas of Basutoland. This study was followed by two of the author's works (Sparrow, 1964, 1965), in which similarly formed topography was described briefly in the south-eastern Drakensberg mountains area. In 1965 Hollingworth confirmed the periglacial origin of these landforms and offered several useful suggestions, the results of which are embodied in the present study.

\section{Problems}

The main problem in the study of any periglacial landforms in Southern Africa is that no traces of Pleistocene glaciation are known to occur. While this adds to the difficulty of the work, it must be pointed out that periglacially modified topography has been successfully identified by the author in the New England region of New South Wales (Australia) over 500 miles $(805 \mathrm{~km}$.) to the north of any Pleistocene glaciation (Sparrow, unpublished, $196 \mathrm{I}$ ). Without the occurrence of nearby glaciated topography as a guide, the identification of periglacial landforms must be undertaken with caution. Block fields, for example, may form under a wide range of conditions other than frost-riving, and slumped head material may be confused with other types of mass-moved debris. Cirques, on the other hand, provide a more 
reliable guide, for as stated by Flint ([1957], p. 97-102) they may form under nival as well as glacial conditions.

\section{The LANDForms}

The features discussed here occur at altitudes between 5,500 and $\mathrm{I}$ I, ooo ft. ( 1,675 and $3,355 \mathrm{~m}$.) in the mountainous uplands of Basutoland and the adjacent Drakensberg mountains near lat. $30^{\circ} \mathrm{S}$. (Fig. I). They are formed upon horizontally bedded shales, sandstones and basalts of the Karroo System as well as a number of large basic intrusions.

It is important to realize that, while the landforms under discussion occupy a relatively small area, periglacial topography seems to be fairly widespread in its distribution in the adjacent uplands of both South Africa and Basutoland above the 6,ooo ft. (r,830 m.) level.

\section{The northern section}

This comprises the prominent upland spur that projects for about 20 miles $(32 \mathrm{~km}$. $)$ south-eastwards into Natal from Giants Castle (Fig. I). Its main portion consists of the ridge of Ntabamnyama $\left(7,5^{1} \mathrm{I} \mathrm{ft}\right.$; $2,290 \mathrm{~m}$.) which lies to the north and east of the deep valley of the Loteni River. This ridge is between 8 and 10 miles ( 12.9 and $16 \cdot 1 \mathrm{~km}$.) long, and is capped by Lower Jurassic Cave Sandstone. The south-western faces of this capping are in marked contrast to its north-eastern flanks; while the latter present a relatively straight plan form, the former exhibit a jagged pattern of innumerable pinnacles and generally craggy topography. Below this capping, the remainder of the slope drops about 2,00o ft. (6ro m.) and is roughly concave in profile. Here, it is covered by irregular rolls and masses of poorly sorted material in which there are massive sandstone blocks often exceeding $100 \mathrm{ft} .(30.5 \mathrm{~m}$. across. While a few of these blocks show signs of having rolled bodily downwards, the majority appear to have moved as an integral part of the main mass.

Dissection of this slumped mass by contemporary streams indicates that movement has now ceased; in addition to this, the numerous erosion gullies clearly indicate the nature of the slumped head. While snow rotting could have caused the shattering and denticulation of some of the higher parts of the cap-rock cliffs, it seems more probable that severe frost action was the main agent. Alternate freezing and thawing during a periglacial regime would have then provided an adequate mechanism for the downward movement of the material by solifluction slumping.

\section{The central section}

This lies between the Loteni River valley in the north and the Cape Province/Natal border in the south (Fig. I). Its western extremities extend into the highland area of Basutoland: an area of gently rolling upland terrain at altitudes between 9, ooo and I I, ooo ft. $(2,745$ and $3,355 \mathrm{~m}$.) lying to the west of the Drakensberg escarpment. To the east of this feature and rising to an altitude of $8,000 \mathrm{ft}$. $(2,440 \mathrm{~m}$.) is a belt of foothill country about $\mathrm{I} 2$ miles $(19.2 \mathrm{~km}$.) in width. Flat-topped spurs project eastward here from the Drakensberg and they are separated by deep canyon-like valleys. To the east, this area is terminated by a girdle of residuals of similar altitude which stand $\mathrm{I}$ mile $(\mathrm{I} .6 \mathrm{~km}$.) or so from the ends of the spurs. While the crest of the Drakensberg and the adjacent Basutoland uplands are formed mainly on basalt, the spurs and residuals comprise Upper Triassic Molteno grits and Red Beds (sandstones and shales) capped by Cave Sandstone.

The tops of both the spurs and residuals are fairly level and they appear on first inspection to be structural features. Closer examination reveals that these "flat" summits are gently undulating and present a topography of broad swells and depressions, many of the latter carrying small swamps and lakes. Air-photograph examination suggests that this surface has been stripped of its overlying basalt cover, for not only is the joint structure extremely 


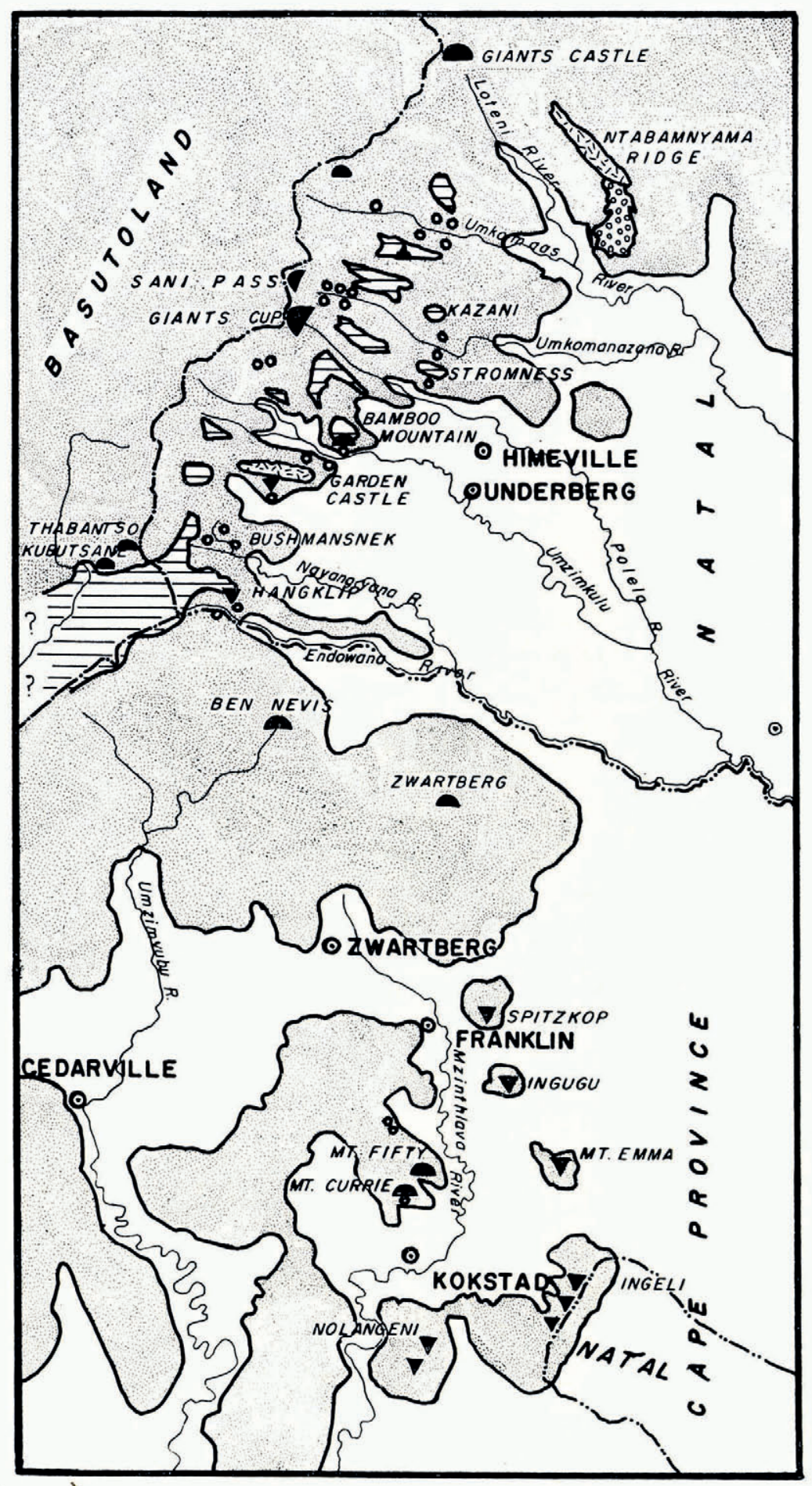

Fig. I. General map of the Drakensberg mountains and Basutoland uplands. The area is Ioo miles ( $161 \mathrm{~km}$.) north to south and 50 miles $\left(80 \mathrm{~km}\right.$.) east to west, and lies between lat. $29^{\circ} 20^{\prime}$ and $30^{\circ} 40^{\prime} \mathrm{S}$. Corresponding longitudes are $29^{\circ}$ oo and $29^{\circ} 4 o^{\prime}$ E. Periglacial features occur above $5,000 \mathrm{fl} .(I, 525 \mathrm{~m}$.) in the stippled area and are shown by the following symbols: cirques, e.g. Giants Castle (black semi-circles); other oversteepened slopes, e.g. Spitzkop (black triangles); possible ice-stripped area, e.g. south of Thaba Niso (horizontal shading); solifluction slumps, e.g. east of Sani Pass (small circles); ice-shattered ridges, e.g. Niabamnyama (random shading) 
prominent but soil cover is almost completely absent, a fact confirmed by field observations. Although no striations have been discovered upon this surface, it seems reasonable to attribute both the stripping and the formation of the undulations to the action of localized thin ice or compacted snow.

Owing to the fact that many periglacial features show strong resemblances from valley to valley in this area, the Umkomanazana River valley has been taken as a type example in order to avoid needless repetition. This valley lies between the Kokotobagi-Kazani ridge and the Stromness-Sakeng spur (Figs. 2-4).

Slumped talus material is widespread on the lower slopes bordering this valley, one such mass occurring on the southern slopes of Kazani. As in the Ntabamnyama ridge examples quoted earlier, both this and other neighbouring masses are composed of poorly sorted

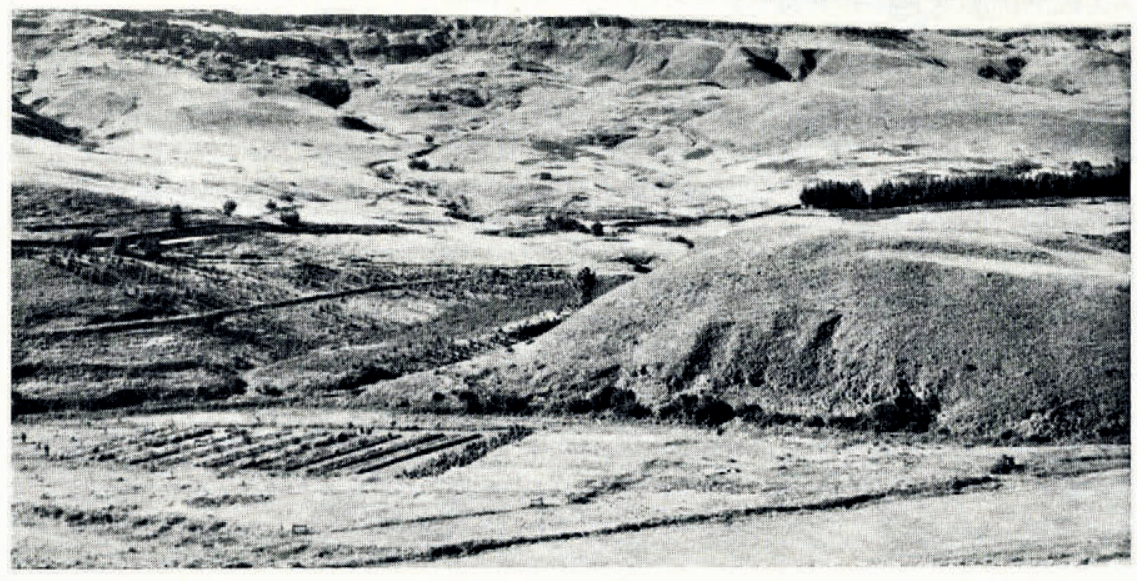

Fig. 2. Stromness ridge, south side of the Umkomanazana River valley, showing large-scale slumping

material and are in the process of dissection by contemporary streams. Farther up-stream (Figs. 3 and 4), this slumping is more widespread and contains numerous large boulders. In several cases the slumped material is clearly seen to have moved downward and to have partially blanketed a number of rock outcrops in the process. Associated with this slumping are large areas of terrain at higher levels upon which there are a number of veneered patches of broken sandstone shards. While contemporary climatic conditions might be responsible for this phenomenon (Sparrow, 1965), its widespread extent throughout the higher regions of Southern Africa suggests that it may have been formed by frost-riving during the Pleistocene.

The slopes in this area show various types of over-steepening on their southern (poleward) aspects. This varies from barely perceptible increases in slope angles to well-defined cirque forms. By far the most striking example at lower levels is seen in the residual of Bamboo Mountain about 5 miles $(8 \mathrm{~km}$.) to the south of the Umkomanazana valley (Fig. 5). This residual is a roughly conical flat-topped mountain rising about 2,00o ft. (610 m.) above the Umzimkulu River valley. Slope angles average $35^{-} 40^{\circ}$ with the exception of those on 


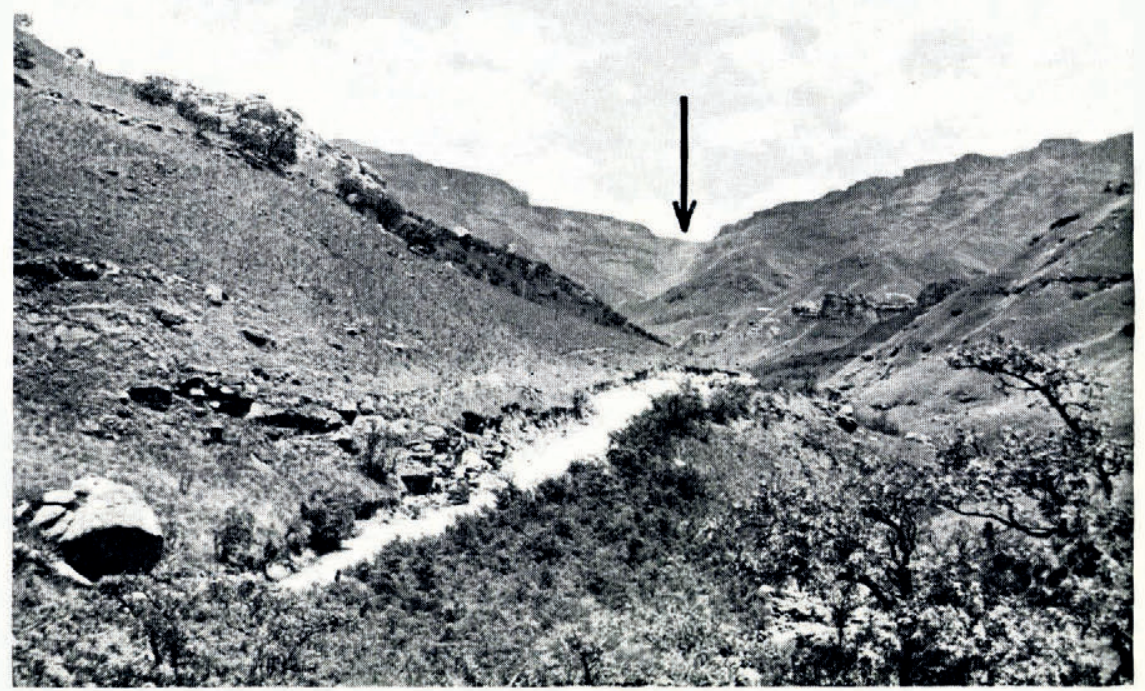

Fig. 3. The upper part of the Umkomanazana River valley looking up-stream to the amphitheatre at Sani Pass (arrowed). A cirque is present at the valley head and there is slumped head on the valley sides in the foreground

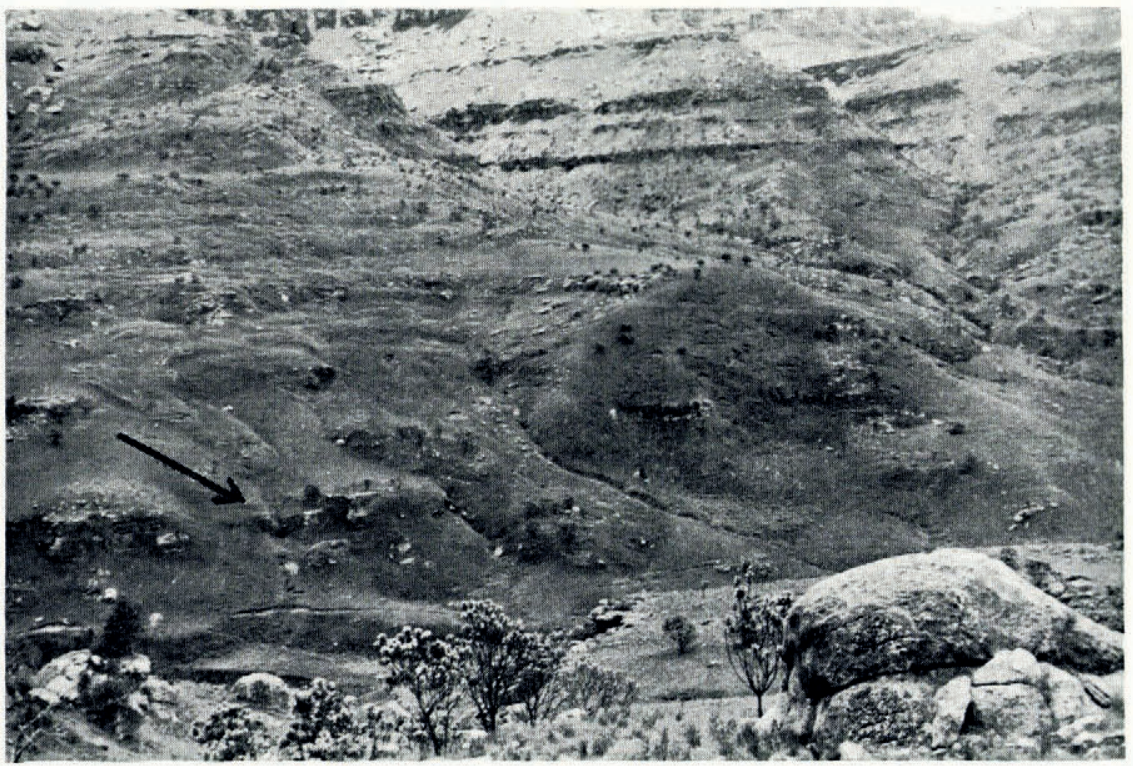

Fig. 4. The Umkomanazana River valley, showing valley-side solifluction slumps with flows blanketing rock outcrops (arrowed) 


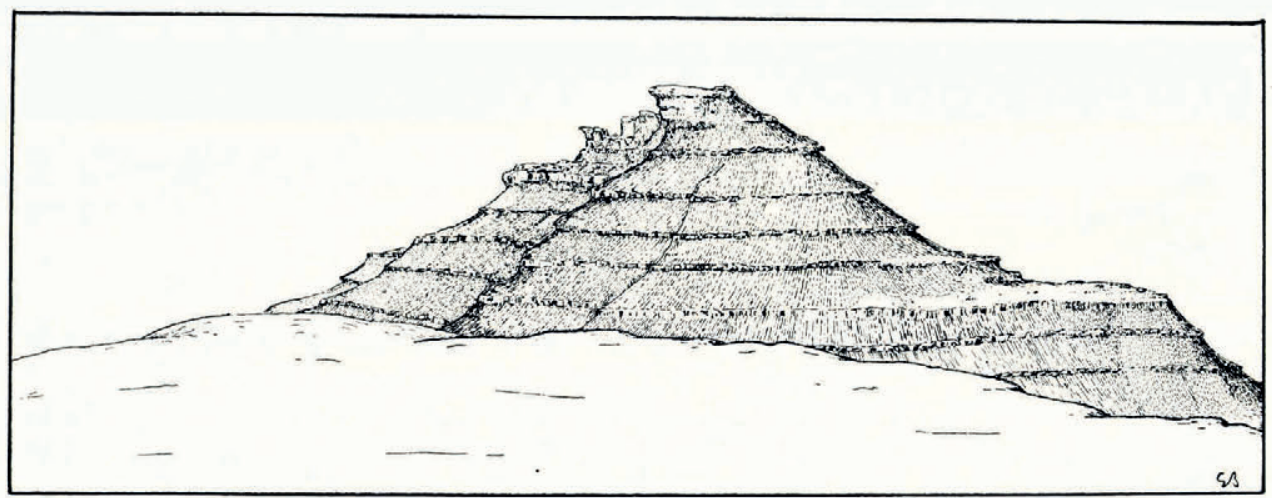

Fig. 5. Bamboo Mountain, showing oversteepening on its southern face (left)

its southern face. Here, there is a vertical to overhanging sandstone cliff below which occurs an irregularly concave slope about $2,000 \mathrm{ft}$. $(6 \mathrm{ro} \mathrm{m}$.) in vertical extent. Slumped material occupies the lower parts of this slope and it terminates in a small dejection cone.

Several more clearly defined cirque-shaped hollows occur above 7,00o ft. (2, I35 m.); the amphitheatre termination of the Umkomanazana valley is a typical example (Fig. 3 ). A far better example, however, is seen about 3 miles $(4.8 \mathrm{~km}$.) to the south at the head of the Polela River valley. Here, the twin summits of Sakeng and Hodgsons Peak bound a hollow known locally as "Giants Cup". This hollow faces east and forms a gigantic bowl of over $3,000 \mathrm{ft}$. (915 m.) depth cutting into the Drakensberg escarpment. Other cirques are the southern faces of Thaba Ntso, Kubutsane, Hangklip and Giants Castle.

\section{The southern section}

The landforms within this area, while agreeing in altitude with those of the two northern areas discussed above, differ in their having been formed almost exclusively on basic intrusions of gabbro and dolerite. They occur in the area of the Cape Province known as East Griqualand and they form blister-like clusters of mountainous topography rising above the plateau terrain of the area.

The Mount Currie hillmass (Fig. I) occupies the centre of this area and it rises to a maximum altitude of $7,297 \mathrm{ft}$. $(2,225 \mathrm{~m}$.). This mountain, the southernmost peak of the hillmass, is a flat-topped, irregularly shaped cone, the southern face of which is in the form of a shallow cirque-like trough. Its vertical extent is $1,200 \mathrm{ft}$. $(365 \mathrm{~m}$.) and a mass of slumped material occupies its base.

Mount Currie is separated from the remainder of the hillmass to the north by a valley that bears some resemblance to the characteristic " $U$ " form of glaciated regions. It is occupied by an underfit stream and its floor is covered with poorly sorted material resembling head. Small cirque-like hollows cut into Mount Fifty on its northern flank.

Several other oversteepened slopes are found in this southern area, and they include Ben Nevis and Zwartberg to the north, and Ingeli and Insizwa to the south. In no case are they as spectacular or as clearly defined as those in the central section to the north.

\section{INTERPRETATION OF EVIDENCE}

All the landforms described above suggest that a cool climatic phase operated at some time during the Pleistocene. Most widespread are the oversteepened slopes which, even today, retain their winter snow cover long after it has melted elsewhere. Despite this supporting 
evidence, it is felt that other types of evidence must be cited if the suggestion of a Pleistocene periglacial regime is to have any validity.

Studies done by Klute (1921) suggest a snow line for lat. $30^{\circ} \mathrm{S}$. at about $12,000 \mathrm{ft}$. (3,66o m.). Flint ([1957], p. 47-49) has suggested that this could be at least 4 , ooo ft. $(\mathrm{r}, 220 \mathrm{~m}$.) lower at $8,000 \mathrm{ft}$. $\left(2,44^{\circ} \mathrm{m}\right.$.). This latter altitude coincides closely with the lowest observed cirques in this area. Below this snow-line level, periglacial landforms occur down to 6,ooo ft. ( $1,830 \mathrm{~m}$.); thus, Alexandre's (1962) minimum level for such phenomena coincides with the present author's field observations.

Van Zinderen Bakker's (1963, I964) palynological work indicates that the Pleistocene climate in Southern Africa fluctuated between pluvial and arid. Flint (1959) suggested that the temperatures during these wetter phases were generally some $10^{\circ} \mathrm{F}$. $\left(5 \cdot 6^{\circ} \mathrm{C}\right.$. $)$ lower than at present, a fact agreed upon by Van Zinderen Bakker (1963, i 964$)$. Thus, the presentday mean annual temperature of $55^{\circ} \mathrm{F}$. ( $12 \cdot 8^{\circ} \mathrm{C}$.) for regions above 7 , 0oo $\mathrm{ft}$. $(2, \mathrm{I} 35 \mathrm{~m}$.) is reduced to $45^{\circ} \mathrm{F} .\left(7 \cdot 2^{\circ} \mathrm{C}\right.$.) and the mean winter temperatures for such areas drop from $45^{\circ}$ to $35^{\circ} \mathrm{F} .\left(7 \cdot 2^{\circ}\right.$ to $\mathrm{I} \cdot 7^{\circ} \mathrm{C}$.). These lower temperatures, together with an increased precipitation during pluvial periods, would have allowed sufficient snowfall to lie and form cirques. When it is realized that the above figures have been quoted for $7,000 \mathrm{ft} .(2, \mathrm{I} 35 \mathrm{~m}$.) and that there is every possibility of Flint's $10^{\circ} \mathrm{F}$. $\left(5 \cdot 6^{\circ} \mathrm{C}\right.$. $)$ temperature drop being a conservative estimate, it will be seen that the case for a periglacial regime becomes stronger, especially when the considerable present-day snowfalls in Basutoland are taken into account.

Van Zinderen Bakker's work ( 1963,1964 ) is also of some value in suggesting a date and duration for a periglacial phase. It is assumed that such a phase must have been of fairly long duration to have left any appreciable traces; thus, the first and second post-pluvial phases were of too short a period $(1,000-1,500 \mathrm{yr}$.). Far more likely is that the landscape was modified during the Gamblian (=Würm (approximately)) pluvial period, dated at 45 , ooo yr. duration. During this time, even a mild periglacial regime would have had time enough to have left considerable traces. Earlier pre-Gamblian pluvial periods may be ruled out for, despite their being quite long enough to have permitted periglacial landscape modification, they were all followed by arid climatic periods of over 50,000 yr. duration which would have almost completely masked any pre-existing periglacial topography.

The altitude/latitude diagram (Fig. 6) shows a progressive rise to the north of the altitudes of periglacial features much as would be expected. The altitudes of the cirques appear to be random on first inspection owing to the maximum altitudes of the East Griqualand summits being $8,000 \mathrm{ft}$. $(2,440 \mathrm{~m}$.) in contrast to $\mathrm{I} 1,000 \mathrm{ft}$. $(3,355 \mathrm{~m}$.) in the Drakensberg to the north. When this is taken into account, it is seen that there is again a progressive increase in cirque-base altitudes towards the north, although in this case it is less regular.

It would appear that, during the Gamblian period of the Pleistocene, Southern Africa was cooler than at present with a snow line at about 8 , ooo $\mathrm{ft}$. $(2,440 \mathrm{~m}$.). Localized snow and ice patches were able to strip the terrain in a few areas and snow remained in sufficient quantity for cirques to form. Severe frost action took place at lower levels and localized permafrost assisted the movement of head by solifluction. At no time was the precipitation sufficient to permit any more than extremely localized ice formation.

\section{AcKNowledgements}

Most of the work discussed here was done while mapping for the Geological Survey of South Africa. The encouragement and assistance of this organization is gratefully acknowledged. In addition, the late Professor S. E. Hollingworth examined many of the field examples during $1964-65$ and he offered the following suggestions:

i. The "extended block masses" of the Ntabamnyama Ridge area might be due to solifluction or even ice-assisted avalanches. 


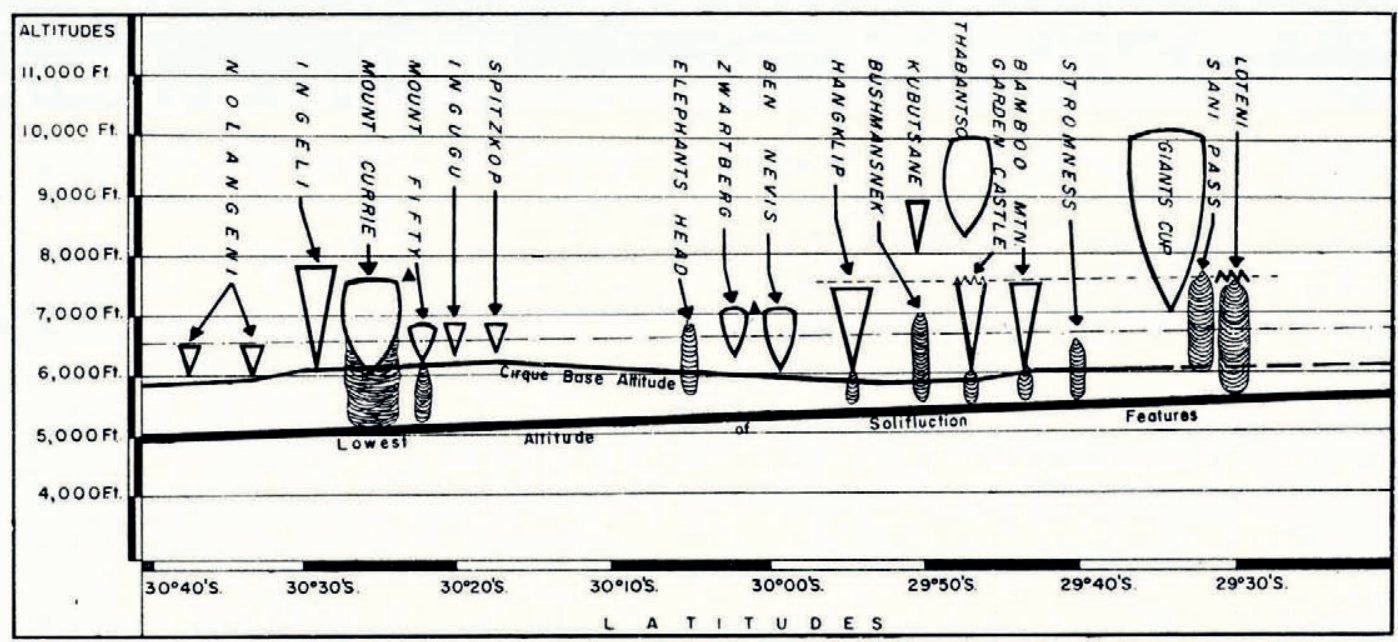

Fig. 6. A diagram showing the relationship between altitudes and latitudes of periglacial features. Cirques are shown as shieldshaped symbols and solifluction slumps as irregularly shaded areas below some of the cirques. The surface of possible ice stripping is shown as a broken line extending from Hangklip to Loteni and is shown associated with frost-shattered summits (wavy line)

ii. Several tors occur at the ends of spurs. These may be "pre-glacial" remnants that have been unaffected by any ice or firn movement.

iii. Several asymmetrical valleys have been thus formed by snow-rotting of their polefacing slopes.

iv. Certain masses of poorly sorted material may be morainic in origin.

While the author is in agreement with most of these suggestions, he feels that avalanching as suggested in (i) can be ruled out, since no signs of any rapid movement have been seen. While small localized snowfields could have formed in some valleys, it is felt that these were far too small to have been able to form moraines as suggested in (iv). Apart from these two criticisms, Professor Hollingworth's suggestions have been amply vindicated in the field.

MS. received Io January 1966

\section{REFERENGES}

Alexandre, J. 1962. Phénomènes périglaciaires dans le Basutoland et le Drakensberg du Natal. Biuletyn Peryglacjalny (Łódż), Nr. I I, p. I I-1 3 .

Du Toit, A. L. 1954. Geology of South Africa. Third edition. Edinburgh, Oliver and Boyd Ltd.

Flint, R. F. [1 957.] Glacial and Pleistocene geology. New York, John Wiley and Sons, Inc.

Flint, R. F. 1959. Pleistocene climates in eastern and southern Africa. Bulletin of the Geological Society of America, Vol. 70, No. 3, p. $343^{-74}$.

Klute, F. 192 I. Uber die Ursachen der letzten Eiszeit. Geographische Zeitschrift, Bd. 27, p. 199-203.

Kojot, D. F. 1948. An investigation into the evidence bearing on recent climatic changes over South Africa. South Africa. Irrigation Department. Memoir.

Łoziński, W. rgog. Über die mechanische Verwitterung der Sandstein im gemässtigen Klima. Bulletin International de l'Académie des Sciences et des Lettres de Cracovie, Classe des Sciences, Mathématiques et Naturelles, An. 1909, i er Semestre, No. I, p. I-25.

Sparrow, G. W. A. Unpublished. The physiography of a transition zone. [M.Sc. thesis, University of New England, Armidale, N.S.W., Australia, 196r.]

Sparrow, G. W. A. 1961. The granitic relief of southern New England. Australian Geographer, Vol. 8, No. 3, p. $132-37$. 
Sparrow, G. W. A. 1964. Pleistocene periglacial landforms in the Southern Hemisphere. South African Journal of Science, Vol. 6o, No. 5, p. 143-47.

Sparrow, G. W. A. 1965 . Observations on slope formation in the Drakensberg and foothills of Natal and East Griqualand. Journal for Geography (Stellenbosch), Vol. 1 1, No. 7, p. 23-25.

Van Zinderen Bakker, E. M. I 963. Palaeobotanical studies. South African fournal of Science, Vol. 59, No. 7, p. 332-40. Van Zinderen Bakker, E. M. 1964. Pollen analysis and its contribution to the palaeoecology of the Quaternary in South Africa. (In Davis, D. H. S., ed. Ecology in South Africa. Amsterdam, North-Holland Publishing Co., p. 24-34.) 